\title{
Meta-analysis of the frequency of intrauterine growth restriction and preterm premature rupture of the membranes in pregnant women with COVID-19
}

\section{COVID-19'lu gebe kadınlarda intrauterin büyüme geriliği ve preterm erken membran rüptürünün sıklığı: Bir meta-analiz}

\author{
(1) Reza Bahrami ${ }^{1}$, (1) David A. Schwartz ${ }^{2}$, (1) Mojgan Karimi-Zarchi ${ }^{3}$, (1) Atiyeh Javaheri ${ }^{4}$, \\ (1) Seyed Alireza Dastgheib ${ }^{5}$, (1) Farzad Ferdosian ${ }^{6}$, (1) Mahmood Noorishadkam ${ }^{7}$, (1) Seyed Reza Mirjalili ${ }^{7}$, \\ (1) Hossein Neamatzadeh ${ }^{8}$
}

\author{
${ }^{1}$ Neonatal Research Center, Shiraz University of Medical Sciences, Shiraz, Iran \\ 2Department of Pathology, Medical College of Georgia, Augusta, GA, USA \\ ${ }^{3}$ Department of Obstetrics and Gynecology, Firoozgar Hospital, Iran University of Medical Sciences, Tehran, Iran \\ ${ }^{4}$ Department of Obstetrics and Gynecology, Shahid Sadoughi University of Medical Sciences, Yazd, Iran \\ 5 Department of Medical Genetics, School of Medicine, Shiraz University of Medical Sciences, Shiraz, Iran \\ ${ }^{6}$ Children Growth Disorder Research Center, Shahid Sadoughi University of Medical Sciences, Yazd, Iran \\ ${ }^{7}$ Mother and Newborn Health Research Center, Shahid Sadoughi University of Medical Sciences, Yazd, Iran \\ 8 Department of Medical Genetics, Shahid Sadoughi University of Medical Sciences, Yazd, Iran
}

\begin{abstract}
The impact of severe acute respiratory syndrome coronavirus-2 (SARS-CoV-2) in pregnancy has yet to be determined. Some studies indicate that SARSCoV-2 infection may be associated with a higher risk of adverse outcomes in pregnant women. Here, we performed a meta-analysis to estimate the frequency of intrauterine growth restriction (IUGR) and preterm premature rupture of the membranes (PPROM) in pregnant women with Coronavirus disease-2019 (COVID-19). A comprehensive search was performed in various databases, such as PubMed, Scopus, SciELO, MedRxiv, and Web of Science, to find all relevant studies published before 10 February 2021. Cross-sectional and consecutive case series reporting the pregnancy outcomes of COVID-19 were included. A total of 24 studies, including 8 studies on IUGR and 16 studies on PPROM, were selected. Pooled data showed that the frequencies of IUGR and PPROM in pregnant women with COVID-19 were $2.6 \%$ and $9.9 \%$, respectively. Analyses stratified by ethnicity showed that the frequencies of IUGR in Asian and Caucasian COVID-19-infected pregnant women were 2.9\% and 2.0\%, respectively. Moreover, the frequencies of PPROM in Asian and Caucasian COVID-19-infected pregnant women were 10.2\% and 5.8\%, respectively. This meta-analysis showed that the frequencies of IUGR and PPROM in COVID-19-infected pregnant women were $2.6 \%$ and $9.9 \%$, respectively. However, well-designed, large-scale and multicenter clinical studies are required to improve and validate these results.

Keywords: COVID-19, SARS-CoV-2, pregnancy, intrauterine growth restriction, preterm premature rupture of membranes

$\mathrm{O} z$

Şiddetli akut solunum sendromu-koronavirüs-2'nin (SARS-CoV-2) gebelikteki etkisi henüz bilinmemektedir. Bazı çalışmalar, SARS-CoV-2 enfeksiyonunun hamile kadınlarda artmış olumsuz sonlanım riski ile ilişkili olabileceğini göstermiştir. Burada, Koronavirüs hastalığı-2019'lu (COVID-19) hamile kadınlarda intrauterin büyüme geriliği (IUGG) ve preterm erken membran rüptürü (PERM) sıklığını tahmin etmek için bir meta-analiz gerçekleștirdik. 10 Şubat 2021 'den önce yayınlanan tüm ilgili çalışmaları bulmak için PubMed, Scopus, SciELO, MedRxiv ve Web of Science'da kapsamlı bir arama yapıldı. Gebe kadınlarda COVID-19'un gebelik sonuçlarını bildiren kesitsel çalışmalar ve ardışık olgu serileri dahil edildi. İUGG üzerine 8 çalışma ve PERM üzerine 16 çalışma olmak üzere toplam 24 çalışma seçildi. Havuzlanmış veriler, COVID-19'lu enfekte kadınlarda İUGG ve PERM sıklığının sırasıyla \%2,6 ve \%9,9 olduğunu göstermiştir. Etnik kökene göre tabakalı analizler, Asyalı ve Kafkasyalı enfekte hamile kadınlarda İUGG sıklığının sırasıyla \%2,9 ve \%2,0 olduğunu göstermiștir. Ayrıca, Asyalı ve Kafkasyalı enfekte gebelerde PERM sıklı̆̆ı sırasıyla \%10,2 ve \%5,8 idi. Bu meta-analiz, COVID-19 ile enfekte
\end{abstract}

Address for Correspondence/Yazışma Adresi: Prof. Mojgan Karimi-Zarchi,

Department of Obstetrics and Gynecology, Firoozgar Hospital, Iran University of Medical Sciences, Tehran, Iran

Phone: +00989372726153E-mail: drkarimi2001@yahoo.com ORCID ID: orcid.org/0000-0002-8734-9971

Received/Geliș Tarihi: 29.05.2021 Accepted/Kabul Tarihi: 12.07.2021

${ }^{\circledR}$ Copyright 2021 by Turkish Society of Obstetrics and Gynecology

Turkish Journal of Obstetrics and Gynecology published by Galenos Publishing House 
hamile kadınlarda İUGG ve PERM sıklığının sırasıyla \%2,6 ve \%9,9 olduğunu göstermiștir. Bununla birlikte, bu sonuçları iyileştirmek ve doğrulamak için iyi tasarlanmış, büyük ölçekli ve çok merkezli klinik çalışmalara ihtiyaç vardır.

Anahtar Kelimeler: COVID-19, SARS-CoV-2, gebelik, intrauterin büyüme geriliği, preterm erken membran rüptürü

\section{Introduction}

Since December 2019, the novel severe acute respiratory syndrome coronavirus-2 (SARS-CoV-2) outbreak has resulted in 120 million cases and over 2.2 million deaths worldwide ${ }^{(1,2)}$. Several viral infections are known to increase the risk of poor neonatal and maternal outcomes during pregnancy ${ }^{(3-5)}$. Maternal physiological changes in pregnancy have a significant impact on the coagulation and immune, respiratory, and cardiovascular systems of the fetus and may have positive or negative effects on Coronavirus disease-2019 (COVID-19) disease progression ${ }^{(6)}$. Some authors have indicated that two previous epidemics of SARS and Middle Eastern respiratory syndrome (MERS$\mathrm{CoV}$ ) were associated with adverse pregnancy and neonatal outcomes $^{(7)}$. Our experiences in pregnancies complicated by infection with the previous coronaviruses have led us to believe that pregnant woman may be vulnerable to the adverse effects of COVID-19. Initial studies on pregnant women have revealed that COVID-19 significantly increases the risk of abortion, preterm birth, stillbirth, intrauterine growth restriction (IUGR), intrauterine death, low birth weight, and case fatality ${ }^{(8,9)}$. Some studies have also demonstrated that maternal COVID-19 could affect the oxygen supply of the fetus, leading to placental insufficiency, IUGR, fetal distress, and/or fetal demise ${ }^{(10)}$. Recent epidemiological and clinical studies have reported different results on the maternal and fetus outcomes of COVID-19(11). The current systematic review and meta-analysis aimed to evaluate these results and determine the frequency of IUGR and PROM in pregnant women with COVID-19.

No definitive evidence of the vertical transmission of SARSCoV-2 infection from mother to child is available in the existing data, but some pregnancy complications, such as premature birth, IUGR, and spontaneous abortion, through COVID-19positive mothers have been reported.

\section{Materials and Methods}

\section{Search Strategies}

We performed a meta-analysis in accordance with the preferred reporting items for systematic reviews and meta-analyses guidelines (http://www.prismastatement.org). This metaanalysis does not contain any studies with human participants performed by any of the authors. Electronic databases, including PubMed/MEDLINE, Europe PMC, Google Scholar, EMBASE, Cochrane Library, SciELO, Springer Link, Technology Journal, Egyptian Knowledge Bank, Chinese Biomedical Database, the China National Knowledge Infrastructure platform, VIP, Chinese literature (Wan Fang), and China science, were comprehensively searched to identify all relevant studies published up to 10 February 2021. Combinations of the following search terms were used (designed using English Medical Subject Headings keywords and Emtree terms): ("COVID-19 virus disease" OR "SARS -CoV-2" OR "SARSCoV-2" OR "2019 novel coronavirus infection" OR "2019$\mathrm{nCoV}$ infection" OR "coronavirus disease" OR "coronavirus disease-19" OR "2019-nCoV disease" OR "COVID-19 virus infection") AND ("IUGR" OR "Intrauterine growth retardation" OR "IUGR") AND ("Premature rupture of membranes" OR "Prelabor rupture of membranes" OR "PPROM"). We restricted our search to human studies and articles published in English, Farsi, and Chinese. An extra search was conducted in the reference lists of the included studies to avoid missing eligible studies that had not been identified in the primary search. The Centers for Disease Control and Prevention and World Health Organization websites were also evaluated.

\section{Inclusion and Exclusion Criteria}

The primary studies were selected according to the following inclusion criteria: 1) case series, case-control, or cohort studies; 2) studies reporting pregnancy outcomes in pregnant women with SARS-CoV-2 infection; 3) studies with sufficient data to calculate odds ratios (ORs) with 95\% confidence intervals (CIs). The following exclusion criteria were also implemented: 1) insufficient data; 2) non-human or in vitro studies; 3) abstracts, case reports, non-consecutive case series, posters, editorials, reviews, conference papers, previous meta-analyses, and nonstandard data presentations; and 4) overlapping and duplicated data.

\section{Data Extraction}

Two authors independently performed title-abstract screening on all primary studies. The full text of the selected articles was also screened, and all necessary data were extracted into a standardized form. In case of disagreement, a third author was involved to reach a consensus for all items. The following features were extracted for pooled estimation: name of the first author, year of publication, country of origin, ethnicity, total number of pregnant women with COVID-19, and numbers of reported PPROM and IUGR. The corresponding author was contacted by email for any missing data. The studies included in this current meta-analysis did not obviously overlap with the subjects in other studies. If a duplicate publication was found or the same population was used in multiple studies, the publication with the larger sample size was included in the meta-analysis.

\section{Statistical Analysis}

The frequency of IUGR and PPROM in pregnant women with SARS-CoV-2 infection was assessed by ORs with 95\% CIs. The 
significance of pooled ORs was determined using the Z-test; here, $\mathrm{p}<0.05$ defined as the significance threshold. Betweenstudy heterogeneity was tested using the Q-statistic test; $\mathrm{p} \leq 0.10$ indicated significant heterogeneity crossing studies. The I2 statistic was used to qualify heterogeneity (range, $0-100 \%$ : $12=0-25 \%$, no heterogeneity; $12=25-50 \%$, moderate heterogeneity; $\mathrm{I} 2=50-75 \%$, large heterogeneity; $\mathrm{I} 2=75-100 \%$, extreme heterogeneity). If significant heterogeneity $(\mathrm{p}<0.1)$ was detected, a random-effects model (i.e., the DerSimonian and Laird method) was selected to pool the data; otherwise, the fixed-effects model (i.e., the Mantel-Haenszel method) was employed. Visual inspection of the funnel plot was used to assess potential publication bias. Moreover, Egger's test was performed to assess the publication bias statistically, and $p<0.05$ was considered statistically significant. If the publication bias tests indicated bias, the Duval and Tweedie "trim-and-fill" method was used to adjust this bias ${ }^{(12)}$. All of the statistical calculations were performed using comprehensive meta-analysis version 2.0 software (Biostat, USA). Two-sided p-values $<0.05$ were considered statistically significant.

\section{Results}

As shown in Figure 1, 484 articles were found in different databases and manual searches; these articles were published up to 10 January 2020. Duplicate articles were removed, and 241 articles remained. All of these articles were screened by

gas

PRISMA 2009 Flow Diagram
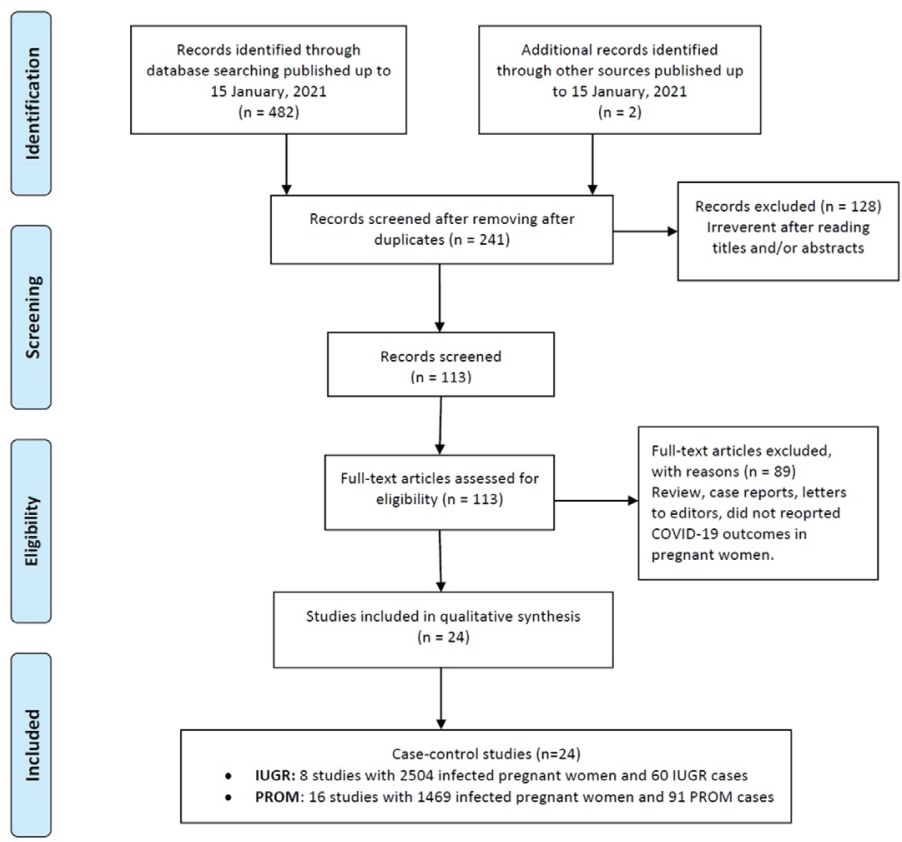

Figure 1. Study selection and inclusion process

IUGR: Intrauterine growth restriction, PPROM: Preterm premature ruptures of membranes, COVID-19: Coronavirus disease-2019 reading their abstracts/titles, and another 128 studies were eliminated. Of the remaining studies, 89 articles were excluded because they were reviews, meta-analyses, or non-consecutive case reports or did not report the necessary data. Finally, a total of 24 studies, including 8 studies on IUGR with 2.504 infected pregnant women and 60 IUGR cases $^{(13-20)}$ and 16 studies on PPROM with 1.469 infected pregnant women and 91 PPROM cases $^{(15,20-34)}$, were selected. The characteristics of the studies included in the present meta-analysis are presented in Table 1. The publication year of the selected studies was 2020 . All selected studies were published in English and Chinese. Among the studies on IUGR, five were performed among Caucasians, two were conducted among Asians and one was conducted among a mixed population. Among the studies on PPROM, nine studies were performed among Asians, four were conducted among Caucasians, and one was conducted among Latin-Americans. The studies were performed in the United States, France, Turkey, Iran, India, Spain, Peru, and China. Quantitative Data Synthesis

\section{IUGR}

Summaries of the frequency of IUGR in pregnant women with SARS-CoV-2 infection are shown in Table 2. The pooled data showed that the frequency of IUGR in COVID-19-infected women was 2.6\% (95\% CI: 0.021-0.034, p $\leq 0.001$, Figure 2A). Analyses stratified by ethnicity showed that the frequencies of IUGR among Asian and Caucasian pregnant women were 2.9\% (95\% CI: $0.020-0.042, \mathrm{p} \leq 0.001)$ and $2.0 \%$ (95\% CI: 0.014-0.031, $\mathrm{p} \leq 0.001$, Figure 2B), respectively. Moreover, the frequency of IUGR among North-American women was $2.5 \%$ (95\% CI: 0.016-0.040, p $\leq 0.001$ ).

\section{PPROM}

Table 2 presents the summaries of the frequency of PPROM among SARS-CoV-2-infected pregnant women. The pooled data showed that the frequency of PPROM among pregnant women infected with COVID-19 was 9.9\% (95\% CI: 0.058-0.164, $\mathrm{p} \leq 0.001$, Figure 3A). Analyses stratified by ethnicity showed that the frequencies of PPROM among Asian and Caucasian infected pregnant women were $10.2 \%$ (95\% CI: 0.056-0.181, $\mathrm{p} \leq 0.001$, Figure 3B) and 5.8\% (95\% CI: 0.011-0.248, p $\leq 0.001$, Figure 3C), respectively. Moreover, the frequency of PPROM among Chinese women was 10.6\% (95\% CI: 0.072-0.155, $\mathrm{p} \leq 0.001)$.

\section{Between-study Heterogeneity and Sensitivity Analysis}

As shown in Table 1, significant between-study heterogeneity was noted in the overall population for PPROM $(I 2=79.27$, $\mathrm{PH} \leq 0.001)$ but not for IUGR $(\mathrm{I} 2=34.02, \mathrm{PH}=0.157)$. Subgroup analysis by ethnicity demonstrated no decrease in heterogeneity. However, subgroup analysis among Chinese women revealed that the country of origin may be a source of heterogeneity in the current meta-analysis (Table 2). We performed a sensitivity analysis to evaluate the stability of the results by sequentially 
A

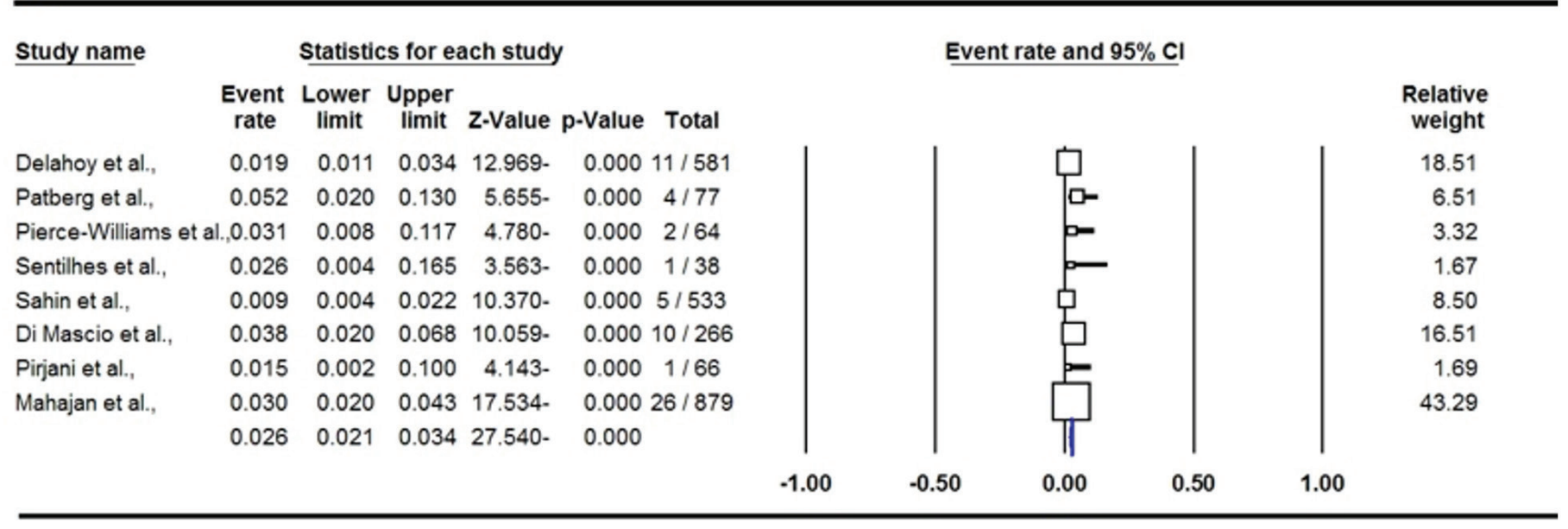

B

\begin{tabular}{|c|c|c|c|c|c|c|}
\hline \multirow[t]{2}{*}{ Study name } & \multicolumn{6}{|c|}{ Statistics for each study } \\
\hline & $\begin{array}{c}\text { Event } \\
\text { rate }\end{array}$ & $\begin{array}{l}\text { Lower } \\
\text { limit }\end{array}$ & $\begin{array}{l}\text { Upper } \\
\text { limit }\end{array}$ & z-Value & p-Value & Total \\
\hline Delahoy et al., & 0.019 & 0.011 & 0.034 & 12.969 & 0.000 & $11 / 581$ \\
\hline Patberg et al., & 0.052 & 0.020 & 0.130 & 5.655 & 0.000 & $4 / 77$ \\
\hline Pierce-Williams et a & al.,, 0.031 & 0.008 & 0.117 & 4.780 & 0.000 & $2 / 64$ \\
\hline Sentilhes et al., & 0.026 & 0.004 & 0.165 & 3.563 & 0.000 & $1 / 38$ \\
\hline Sahin et al., & 0.009 & 0.004 & 0.022 & 2 10.370 & 0.000 & $5 / 533$ \\
\hline & 0.020 & 0.014 & 0.031 & 18.334- & 0.000 & \\
\hline
\end{tabular}

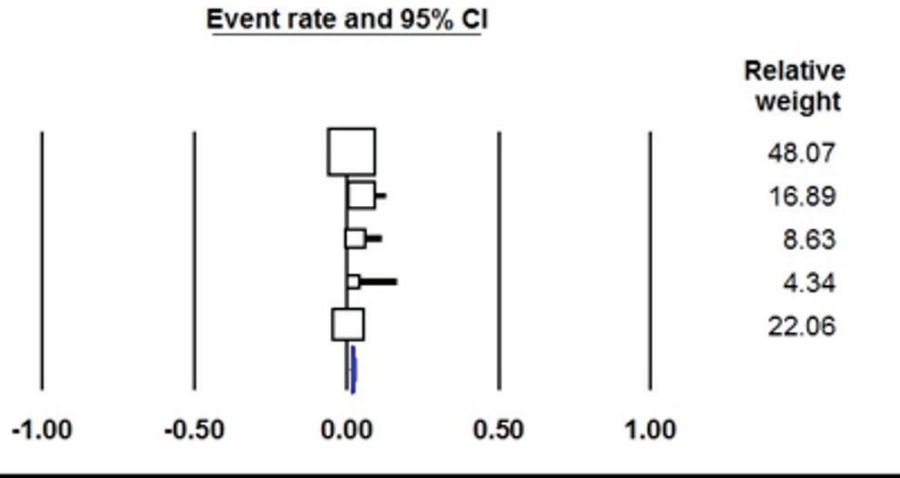

Figure 2. Forest plots of the frequency of IUGR in pregnant women infected with SARS-CoV-2 in the (A) overall and (B) Caucasian populations

IUGR: Intrauterine growth restriction, CI: Confidence interval, SARS-CoV-2: Severe acute respiratory syndrome coronavirus-2

removing each study and then recalculating the corresponding ORs. The data from the sensitivity analysis revealed that none of the studies changed the pooled ORs for IUGR and PPROM, thereby indicating that our combined data are reliable.

Publication Bias

We performed the Begg's and Egger's tests to detect potential publication bias. As shown in Figure 4, the symmetrical funnel plot indicated a significant publication bias for IUGR (PBeggs=0.035; PEggers=0.707) in the overall population but not for PPROM (PBeggs=0.444, PEggers=0.512). Egger's test was performed to provide statistical evidence of the funnel plot (Table 2). The Duval and Tweedie non-parametric "trimand-fill" method was used to adjust for publication bias. Metaanalyses with and without using the "trim-and-fill" method did not result in different conclusions (Figure 4A).

\section{Discussion}

The impact of COVID-19 on pregnancy outcomes remains poorly understood $^{(1,35,36)}$. The clinical course of COVID-19 in pregnant women has been reported to be similar to that in non-pregnant women ${ }^{(37)}$. Patberg et al. ${ }^{(14)}$ found in a retrospective study that the frequency of fetal vascular malperfusion abnormalities was significantly higher in pregnant women than in non-pregnant women with COVID-19 by using a multivariable model adjusted for maternal age, ethnicity, preeclampsia, mode of delivery, IUGR/FGR, and oligohydramnios. Placental abnormalities, such as maternal vascular malperfusion, in pregnant women with COVID-19 have also been associated with IUGR ${ }^{(27,38,39)}$. Studies on pregnant women during previous outbreaks of SARS and MERS observed an increased risk of IUGR. Thus, surveillance of IUGR in women with SARS-CoV-2 infection is recommended because IUGR is often observed in ongoing pregnancies with SARS-CoV-2 ${ }^{(37,38)}$.

The incidence of IUGR among pregnant women has been reported to be between $4 \%$ and $7 \%{ }^{(40)}$. A recent cohort study involving 4.451 Chinese women found that the incidence of IUGR was $22.4 \%$ in women with severe preeclampsia and $18.6 \%$ in women with chronic hypertension with superimposed preeclampsia ${ }^{(41)}$. Diriba et al. ${ }^{(42)}$ performed a meta-analysis on the maternal outcomes of coronavirus infection (i.e., SARS- 
A

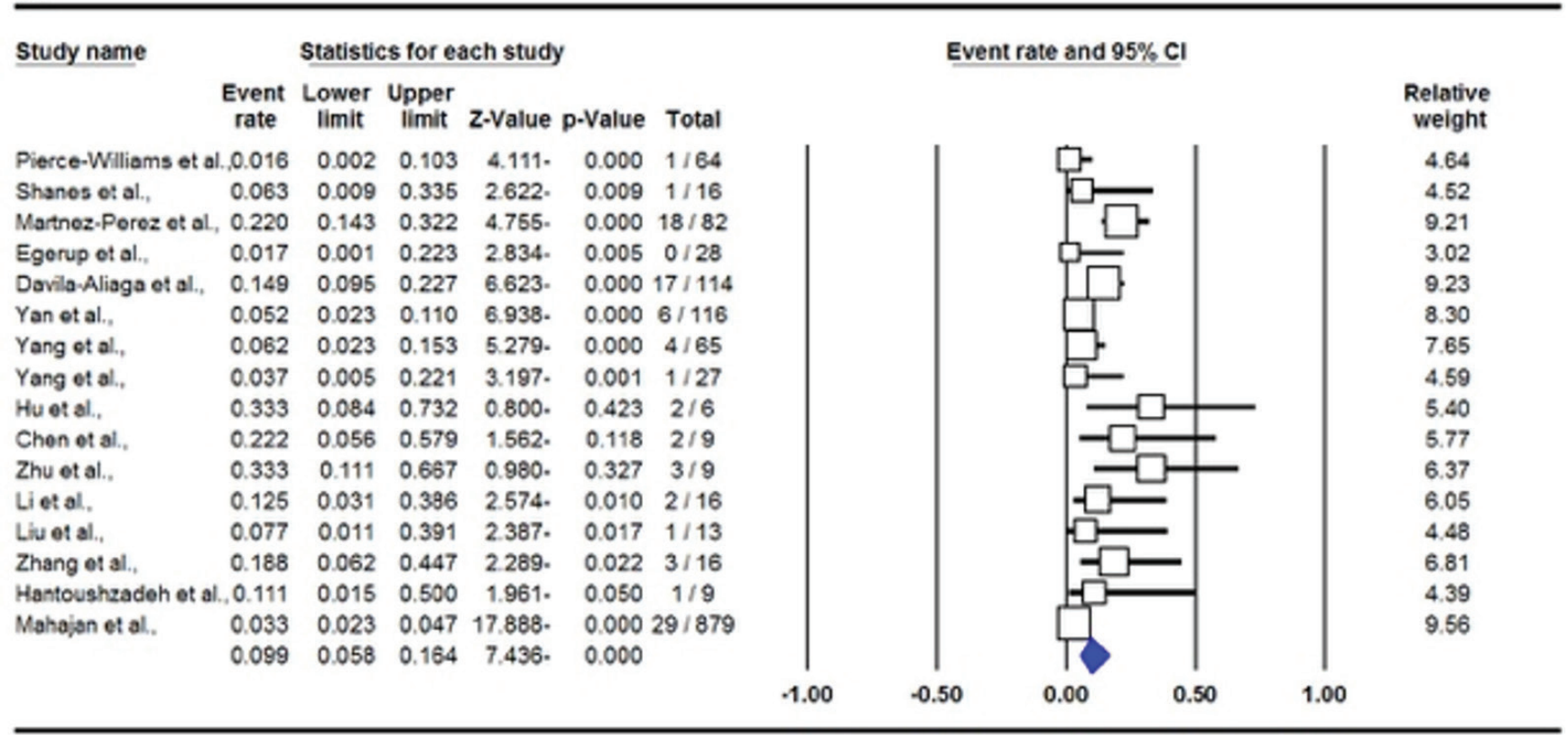

B

\begin{tabular}{|c|c|c|c|c|c|c|}
\hline \multirow[t]{2}{*}{ Study name } & \multicolumn{6}{|c|}{ Statistics for each study } \\
\hline & $\begin{array}{c}\text { Event } \\
\text { rate }\end{array}$ & $\begin{array}{l}\text { Lower } \\
\text { limit }\end{array}$ & $\begin{array}{l}\text { Upper } \\
\text { limit }\end{array}$ & z-Value & p-Value & Total \\
\hline Yan et al., & 0.052 & 0.023 & 0.110 & $6.938-$ & 0.000 & $6 / 116$ \\
\hline Yang et al., & 0.062 & 0.023 & 0.153 & 5.279 & 0.000 & $4 / 65$ \\
\hline Yang et al., & 0.037 & 0.005 & 0.221 & 3.197 - & 0.001 & $1 / 27$ \\
\hline Hu et al., & 0.333 & 0.084 & 0.732 & 0.800 & 0.423 & $2 / 6$ \\
\hline Chen et al., & 0.222 & 0.056 & 0.579 & 1.562 & 0.118 & $2 / 9$ \\
\hline Zhu et al., & 0.333 & 0.111 & 0.667 & 0.980 & 0.327 & $3 / 9$ \\
\hline Li et al., & 0.125 & 0.031 & 0.386 & $2.574-$ & 0.010 & $2 / 16$ \\
\hline Liu et al. & 0.077 & 0.011 & 0.391 & 2.387- & 0.017 & $1 / 13$ \\
\hline Zhang et al., & 0.188 & 0.062 & 0.447 & 2.289 & 0.022 & $3 / 16$ \\
\hline Hantoushzadeh et al & al., 0.111 & 0.015 & 0.500 & 1.961 . & 0.050 & $1 / 9$ \\
\hline Mahajan et al., & 0.033 & 0.023 & 0.047 & $17.888-$ & 0.000 & $29 / 879$ \\
\hline & 0.102 & 0.056 & 0.181 & 6.411- & 0.000 & \\
\hline
\end{tabular}

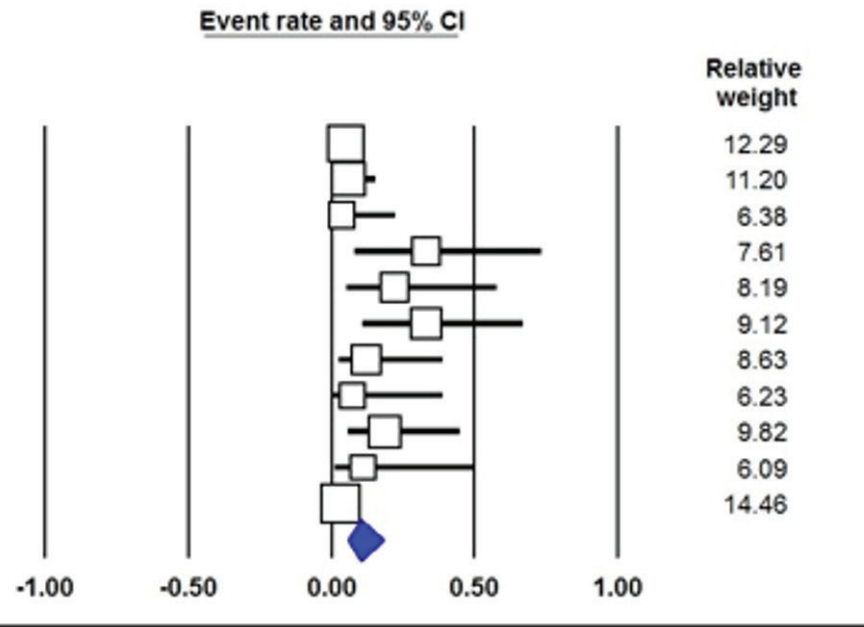

C

Study name

Statistics for each study

Event rate and $95 \% \mathrm{Cl}$

Event Lower Upper

rate limit limit $Z$-Value $p$-Value Total

$\begin{array}{llllll}\text { Pierce-Williams et al } 0.016 & 0.002 & 0.103 & 4.111- & 0.000 & 1 / 64\end{array}$

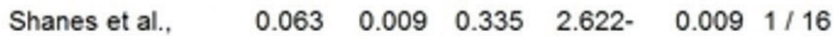

$\begin{array}{llllll}\text { Martnez-Perez et al., } 0.220 & 0.143 & 0.322 & 4.755- & 0.000 & 18 / 82\end{array}$

$\begin{array}{lllllll}\text { Egerup et al., } & 0.017 & 0.001 & 0.223 & 2.834- & 0.005 & 0 / 28\end{array}$

$\begin{array}{llllll}0.058 & 0.011 & 0.248 & 3.252- & 0.001\end{array}$

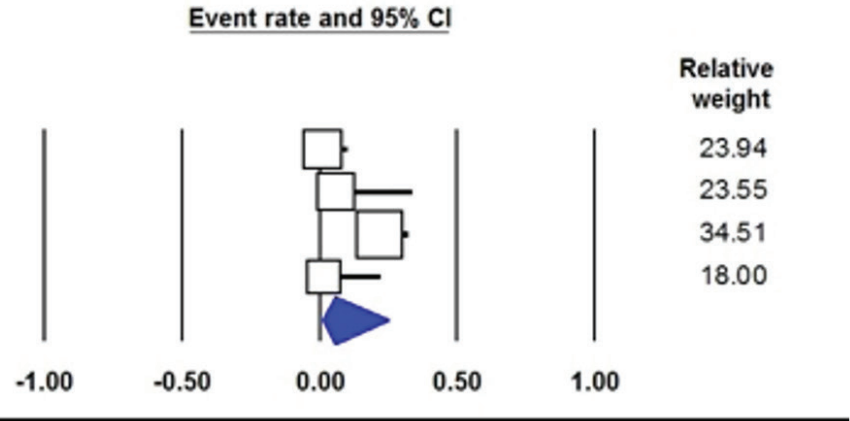

Figure 3. Forest plots of the frequencies of PPROM in pregnant women with SARS-CoV-2 infection in the (A) overall, (B) Asian, and (C) Caucasian populations

PPROM: Preterm premature rupture of the membranes, SARS-CoV-2: Severe acute respiratory syndrome coronavirus-2, CI: Confidence interval 

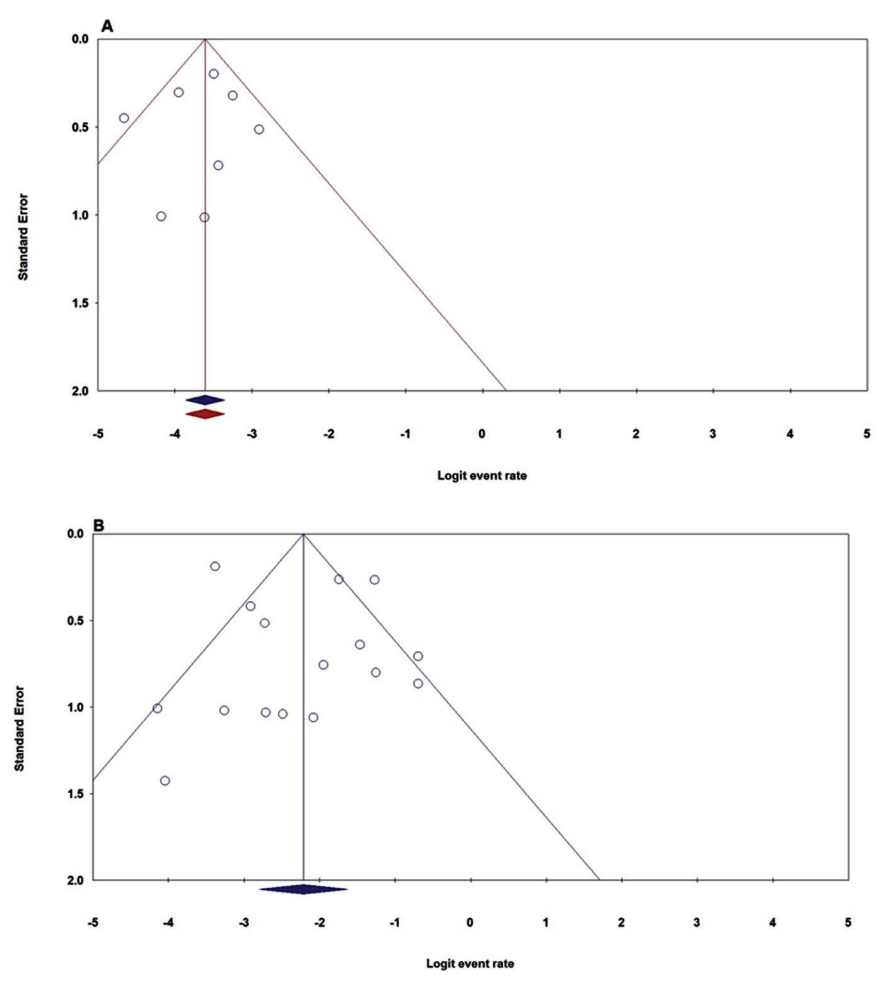

Figure 4. Begg's funnel plot to test for publication bias test on the frequencies of (A) IUGR and (B) PPROM in pregnant women with SARS-CoV-2

PPROM: Preterm premature rupture of the membranes, SARSCoV-2: Severe acute respiratory syndrome coronavirus-2, IUGR: Intrauterine growth restriction

CoV-2, MERS-CoV, and SARS-CoV) and found that the rates of preterm birth (<37 weeks of gestation), preeclampsia, miscarriage, PPROM, and FGR were $14.3 \%, 5.9 \%, 14.5 \%$, $9.2 \%$, and $2.8 \%$, respectively. The pooled data revealed that the incidence rates of PPROM and FGR among pregnant women with SARS-CoV-2 infection were $8.9 \%$ and $1.2 \%$, respectively. Moreover, the group showed that the incidence rates of PPROM and FGR among pregnant women with SARS-CoV infection were $12.5 \%$ and $12.5 \%$, respectively. The current meta-analysis revealed found that the frequency of IUGR in COVID-19 infected pregnant women was $2.6 \%$. This incidence is lower than that determined by others in previously published studies on healthy and infected women ${ }^{(40-42)}$. Biasucci et al. ${ }^{(11)}$, in a study among 375 Italian pregnant women, demonstrated that COVID-19 was not associated with poorer clinical outcomes and/or with higher rates of preterm birth and IUGR in infected pregnant women compared with non-infected pregnant women. PPROM is defined as the rupture of the fetal membrane prior to the onset of labor at less than 37 weeks of gestation. The incidence of PPROM has been reported to be approximately $3 \%{ }^{(40)}$. However, this incidence varies by ethnicity and region. A retrospective cohort study reported that the incidence of PROM among African-Americans was 29.5\%; another study showed that the incidence of PROM in Rochester, NY, USA, was $12.0 \%{ }^{(43)}$. In 2019, Sae-Lin and Wanitpongpan ${ }^{(44)}$ reported that the incidence of PPROM over a 5-year period in Thailand was 2.93\%. Our pooled data showed that the frequency of PPROM was $9.9 \%$ in COVID-19-infected pregnant women; this figure is substantially higher than that indicated in previous research. Subgroup analysis by ethnicity showed that the respective frequencies of PPROM in COVID-19-infected pregnant women were 10.2\% in Asians and 5.8\% in Caucasians. This frequency was $10.6 \%$ in Chinese women. Rodrigues et al. ${ }^{(45)}$ performed a systematic review including 3.985 COVID-19-infected pregnant women and found that the most frequent obstetric conditions include gestational diabetes (4.5\%), PPROM (2.7\%), preeclampsia/eclampsia/HELLP syndrome (1.7\%), fetal distress $(1.1 \%)$, gestational hypertension $(0.6 \%)$, fetal growth restriction $(0.4 \%)$, placenta previa/placental abruption/placenta accreta (0.4\%), and oligohydramnios/polyhydramnios (0.2\%). Chi et al. ${ }^{(46)}$, in a meta-analysis including 230 women with COVID-19 and 156 newborns, showed that 8.49\% (9/106) of the newborns had PPROM. Della Gatta et al. ${ }^{(4)}$ conducted a review of six studies including 51 pregnant women and found PPROM in at least 9 of 34 patients (26\%). Akhtar et al. ${ }^{(48)}$ performed a meta-analysis and determined that the most common maternal/fetal complications included intrauterine/ fetal distress (14\%) and PPROM (8\%). Moreover, the group found that COVID-19 infection in pregnancy leads to increased risk of pregnancy complications, such as preterm birth and PPROM, and may even lead to maternal death in rare cases. Yang et al. ${ }^{(32)}$, in a study based on the Maternal and Child Health Information System of Wuhan, China, showed no significant difference in the incidence of PPROM between the confirmed and free COVID-19 groups. Zhang et al. ${ }^{(26)}$, in a case-control study among pregnant women with and without COVID-19 in Hubei, China, reported no significant difference between pregnant women in terms of gestational diabetes, severe preeclampsia, PPROM, fetal distress, meconium-stained amniotic fluid, premature delivery, neonatal asphyxia, and procedures for severe post-partum bleeding.

Our meta-analysis presents potential limitations. First, all of the included studies were performed among Caucasian and Asian pregnant women with COVID-19. Thus, our pooled data are not generalizable to other ethnicities. Further studies with larger sample sizes in different ethnicities are necessary to confirm our findings. Second, the studies included in the current metaanalysis were published in English and Chinese; thus, a number of potentially significant data published in other languages may have been excluded. Finally, in the current meta-analysis, we could not answer some important questions, such as the extent of asymptomatic or mild infection and the effect on IUGR and PPROM, because of the lack of data in primary studies.

In summary, this meta-analysis showed that the frequencies of IUGR and PPROM in COVID-19-infected pregnant women were $2.6 \%$ and $9.9 \%$, respectively. Analyses stratified by 
ethnicity revealed that the frequencies of IUGR and PPROM were higher in Asian COVID-19-infected pregnant women than in Caucasian COVID-19-infected women. Given that most studies on COVID-19 included cases with early stages of the disease and that the selected reports were restricted to China, further well-designed studies with larger sample sizes including different populations may be required to obtain more accurate estimates.

\section{Ethics}

Peer-review: Externally peer-reviewed.

\section{Authorship Contributions}

Concept: R.B., D.A.S., M.K.Z., Design: R.B., D.A.S., M.K.Z., Data Collection or Processing: M.K.Z., Analysis or Interpretation: S.R.M., H.N., Literature Search: M.N., A.J., S.A.D., F.F., Writing: M.N., R.B.

Conflict of Interest: No conflict of interest was declared by the authors.

Financial Disclosure: The authors declared that this study received no financial support.

\section{References}

1. Karimi-Zarchi M, Neamatzadeh H, Dastgheib SA, Abbasi H, Mirjalili SR, Behforouz A, et al. Vertical transmission of coronavirus disease 19 (covid-19) from infected pregnant mothers to neonates: a review. Fetal Pediatr Pathol 2020;39:246-50.

2. Mirjalili H, Dastgheib SA, Shaker SH, Bahrami R, Mazaheri M, SadrBafghi SMH, et al. Proportion and mortality of Iranian diabetes mellitus, chronic kidney disease, hypertension and cardiovascular disease patients with COVID-19: a meta-analysis. J Diabetes Metab Disord 2021;20:905-17.

3. Racicot K, Mor G. Risks associated with viral infections during pregnancy. J Clin Invest 2017;127:1591-9.

4. Silasi M, Cardenas I, Kwon JY, Racicot K, Aldo P, Mor G. Viral infections during pregnancy. Am J Reprod Immunol 2015;73:199213.

5. Noorishadkam M, Lookzadeh MH, Mazaheri M, Mirjalili SR, Bahrami R, Asadian F, et al. Coronavirus disease 2019 (COVID-19) and late pregnancy loss in infected pregnant women: a mini review. World J Peri Neonatol 2020;2:67-70.

6. Wastnedge EAN, Reynolds RM, van Boeckel SR, Stock SJ, Denison FC, Maybin JA, et al. Pregnancy and COVID-19. Physiol Rev 2021;101:303-18.

7. Lambelet V, Vouga M, Pomar L, Favre G, Gerbier E, Panchaud A, et al. SARS-CoV-2 in the context of past coronaviruses epidemics: Consideration for prenatal care. Prenat Diagn 2020;40:1641-54.

8. Chen S, Liao E, Cao D, Gao Y, Sun G, Shao Y. Clinical analysis of pregnant women with 2019 novel coronavirus pneumonia. J Med Virol 2020;92:1556-61.

9. Abou Ghayda R, Li H, Lee KH, Lee HW, Hong SH, Kwak M, et al. COVID-19 and adverse pregnancy outcome: a systematic review of 104 cases. J Clin Med 2020;9:3441.

10. Seymen CM. Being pregnant in the COVID-19 pandemic: effects on the placenta in all aspects. J Med Virol 2021;93:2769-73.

11. Biasucci G, Cannalire G, Raymond A, Capra ME, Benenati B, Vadacca $G$, et al. Safe perinatal management of neonates born to SARS-
CoV-2 positive mothers at the epicenter of the italian epidemic. Front Pediatr 2020;8:565522. doi:10.3389/fped.2020.565522

12. Bahrami R, Dastgheib SA, Niktabar SM, Amooee A, Lookzadeh MH, Mirjalili SR, et al. Association of BMP4 rs17563 polymorphism with nonsyndromic cleft lip with or without cleft palate risk: literature review and comprehensive meta-analysis. Fetal Pediatr Pathol 2021;40:305-19.

13. Delahoy MJ, Whitaker M, O'Halloran A, Chai SJ, Kirley PD, Alden N, et al. Characteristics and maternal and birth outcomes of hospitalized pregnant women with laboratory-confirmed COVID-19 - COVID-NET, 13 States, March 1-August 22, 2020. MMWR Morb and Mortal Wkly Rep 2020;69:1347-54.

14. Patberg ET, Adams T, Rekawek P, Vahanian SA, Akerman M, Hernandez A, et al. COVID-19 infection and placental histopathology in women delivering at term. Am J Obstet Gynecol 2020;S0002-9378(21):00605-0. doi:10.1016/j.ajog.2020.10.020

15. Pierce-Williams RAM, Burd J, Felder L, Khoury R, Bernstein PS, Avila K, et al. Clinical course of severe and critical coronavirus disease 2019 in hospitalized pregnancies: a United States cohort study. American Journal of Obstetrics \& Gynecology MFM 2020;2:100134.

16. Sentilhes L, De Marcillac F, Jouffrieau C, Kuhn P, Thuet V, Hansmann Y, et al. Coronavirus disease 2019 in pregnancy was associated with maternal morbidity and preterm birth. Am J Obstet Gynecol 2020;223:914.e1-15. doi:10.1016/j.ajog.2020.06.022

17. Sahin D, Tanacan A, Erol SA, Anuk AT, Yetiskin FDY, Keskin HL, et al. Updated experience of a tertiary pandemic center on 533 pregnant women with COVID-19 infection: a prospective cohort study from Turkey. Int J Gynecol Obstet 2021;152:328-34.

18. Di Mascio D, Saccone G, Sen C, Di MD, Galindo A, Grünebaum A, et al. Maternal and Perinatal Outcomes of Pregnant Women with SARSCOV-2 infection. Ultrasound Obstet Gynecol 2021;57:232-41.

19. Pirjani R, Hosseini R, Soori T, Rabiei M, Hosseini L, Abiri A, et al. Maternal and neonatal outcomes in COVID-19 infected pregnancies: a prospective cohort study. J Travel Med 2020;27:taaa158. doi: 10.1093/jtm/taaa158.

20. Mahajan NN, Ansari M, Gaikwad C, Jadhav P, Tirkey D, Pophalkar $\mathrm{MP}$, et al. Impact of SARS-CoV-2 on multiple gestation pregnancy. Int J Gynaecol Obstet 2021;152:220-5.

21. Chen H, Guo J, Wang C, Luo F, Yu X, Zhang W, et al. Clinical characteristics and intrauterine vertical transmission potential of COVID-19 infection in nine pregnant women: a retrospective review of medical records. Lancet 2020;395:809-15.

22. Zhu H, Wang L, Fang C, Peng S, Zhang L, Chang G, et al. Clinical analysis of 10 neonates born to mothers with 2019-nCoV pneumonia. Transl Pediatr 2020;9:51-60.

23. Li N, Han L, Peng M, Lv Y, Ouyang Y, Liu K, et al. Maternal and neonatal outcomes of pregnant women with COVID-19 pneumonia: a case-control study. Clin Infect Dis 2020;71:2035-41.

24. Liu Y, Chen H, Tang K, Guo Y. Clinical manifestations and outcome of SARS-CoV-2 infection during pregnancy. J Infect. 2021;S01634453:30109-2. doi:10.1016/j.jinf.2020.02.028

25. Hantoushzadeh S, Shamshirsaz AA, Aleyasin A, Seferovic MD, Aski SK, Arian SE, et al. Maternal death due to COVID-19. AmJ Obstet Gynecol 2020;223:109.el-6. doi:10.1016/j.ajog.2020.04.030

26. Zhang L, Jiang Y, Wei M, Cheng BH, Zhou XC, Li J, et al. [Analysis of the pregnancy outcomes in pregnant women with COVID-19 in Hubei Province]. Zhonghua Fu Chan Ke Za Zhi 2020;55:E009. doi:10.3760/cma.j.cn112141-20200218-00111 
27. Shanes ED, Mithal LB, Otero S, Azad HA, Miller ES, Goldstein JA. Placental pathology in COVID-19. Am J Clin Pathol 2020;154:23-32.

28. Egerup P, Olsen LF, Hellerung Christiansen A-M, Westergaard D, Severinsen ER, Hviid KV, et al. Severe Acute Respiratory syndrome coronavirus 2 (SARS-CoV-2) antibodies at delivery inwomen, partners, and newborns. Obstet Gynecol 2021;137:49-55.

29. Martínez-Perez O, Vouga M, Cruz Melguizo S, Forcen Acebal L, Panchaud A, Muñoz-Chápuli M, et al. Association between mode of delivery among pregnant women with COVID-19 and maternal and neonatal outcomes in Spain. JAMA 2020;324:296-9.

30. Dávila-Aliaga C, Espínola-Sánchez M, Mendoza-Ibáñez E, GuevaraRíos E, Torres-Marcos E, Hinojosa-Pérez R, et al. Resultados perinatales y serológicos en neonatos de gestantes seropositivas para SARS-CoV-2: estudio transversal descriptivo. Medwave 2020;20:e8084. doi:10.5867/MEDWAVE.2020.11.8084

31. Yan J, Guo J, Fan C, Juan J, Yu X, Li J, et al. Coronavirus disease 2019 in pregnant women: a report based on 116 cases. Am J of Obstet Gynecol 2020;223:111.el-111.e14. doi:10.1016/j. ajog.2020.04.014

32. Yang R, Mei H, Zheng T, Fu Q, Zhang Y, Buka S, et al. Pregnant women with COVID-19 and risk of adverse birth outcomes and maternal-fetal vertical transmission: a population-based cohort study in Wuhan, China. BMC Med 2020;18:330.

33. Yang H, Hu B, Zhan S, Yang LY, Xiong G. Effects of severe acute respiratory syndrome coronavirus 2 infection on pregnant women and their infants: a retrospective study in Wuhan, China. Arch Pathol Lab Med 2020;144:1217-22.

34. Hu X, Gao J, Wei Y, Chen H, Sun X, Chen J, et al. Managing preterm infants born to COVID-19 mothers: evidence from a retrospective cohort study in Wuhan, China. Neonatology 2021;18:330.

35. Freitas-Jesus JV, Rodrigues L, Surita FG. The experience of women infected by the COVID-19 during pregnancy in Brazil: aqualitative study protocol. Reprod Health 2020;17:108.

36. Madjunkov M, Dviri M, Librach C. A comprehensive review of the impact of COVID-19 on human reproductive biology, assisted reproduction care and pregnancy: a Canadian perspective. J Ovarian Res 2020;13:140.

37. Wang C-L, liu Y-Y, Wu C-H, Wang C-Y, Wang C-H, Long C-Y Impact of COVID-19 on pregnancy. Int J Med Sci 2020;18:763-7.
38. Cavalcante MB, Cavalcante CT de MB, Sarno M, Barini R, Kwak-Kim J. Maternal immune responses and obstetrical outcomes of pregnant women with COVID-19 and possible health risks of offspring. J Reprod Immun 2021;143:103250. doi:10.1016/j.jri.2020.103250

39. Prochaska E, Jang M, Burd I. COVID-19 in pregnancy: placental and neonatal involvement. American Journal of Reproductive Immunology. 2020;84:e13306. doi: 10.1111/aji.13306.

40. Cunningham FG, Leveno K, Bloom S, Spong C, Dashe J, Hoffman B, et al. Williams Obstetrics, 25e, AccessMedicine. New York: McGraw Hill Medical; 2018.

41. Zhu Y-C, Lin L, Li B-Y, Li X-T, Chen D-J, Zhao X-L, et al. Incidence and Clinical Features of Fetal Growth Restriction in 4451 Women with Hypertensive Disorders of Pregnancy. Mat Fetal Med 2020;2:207-10.

42. Diriba K, Awulachew E, Getu E. The effect of coronavirus infection (SARS-CoV-2, MERS-CoV, and SARS-CoV) during pregnancy and the possibility of vertical maternal-fetal transmission: a systematic review and meta-analysis. Eur J Med Res 2020;25:39.

43. Han Y, Wang W, Wang X, Dong T, van Donkelaar A, Martin R $\mathrm{V}$, et al. Prenatal exposure to fine particles, premature rupture of membranes and gestational age: A prospective cohort study. Environ Int 2020;145:106146. doi:10.1016/j.envint.2020.106146

44. Sae-Lin P, Wanitpongpan P. Incidence and risk factors of preterm premature rupture of membranes in singleton pregnancies at Siriraj Hospital. J Obstet Gynaecol Res 2019;45:573-7.

45. Rodrigues C, Baía I, Domingues R, Barros H. Pregnancy and Breastfeeding During COVID-19 Pandemic: A Systematic Review of Published Pregnancy Cases. Front Public Health. 2020;8:558144. doi:10.3389/fpubh.2020.558144.

46. Chi J, Gong W, Gao Q. Clinical characteristics and outcomes of pregnant women with COVID-19 and the risk of vertical transmission: a systematic review. Arch Gynecol Obstet 2020;303:337-45.

47. Della Gatta AN, Rizzo R, Pilu G, Simonazzi G. Coronavirus disease 2019 during pregnancy: a systematic review of reported cases. Am J Obstet Gynecol 2020;223:36-41.

48. Akhtar H, Patel C, Abuelgasim E, Harky A. COVID-19 (SARSCoV-2) infection in pregnancy: a systematic review. Gynecol Obstet Invest 2020;85:295-306. 